\title{
DISTRIBUSI PUPUK BERSUBSIDI DI KABUPATEN BANTUL PROVINSI DAERAH ISTIMEWA YOGYAKARTA
}

\section{(The Distribution of Subsidized Fertilizer in Bantul Regency Daerah Istimewa Yogyakarta Province)}

\section{Agus Dwi Nugroho, Abi Pratiwa Siregar, Erlinda Andannari, Yahya Shafiyudin dan Julia Inka Christie}

Program Studi Ekonomi Pertanian/Agrobisnis, Fakultas Pertanian Universitas Gadjah Mada'

\author{
J1 Flora Bulaksumur Yogyakarta 55281 \\ email : agus.dwi.n@mail.ugm.ac.id
}

Diterima 8 Februari 2018, disetujui 4 April 2018

\begin{abstract}
ABSTRAK
Tujuan kajian ini untuk mengetahui ketersediaan dan kebutuhan, mengevaluasi pelaksanaan dan merumuskan saran dalam pengembangan distribusi pupuk di Kabupaten Bantul Provinsi Daerah Istimewa Yogyakarta. Kajian dilaksanakan Mei dan Juni 2017. Responden penelitian antara lain distributor, pengecer, kelompok tani dan petani. Analisis tren digunakan untuk menentukan ketersediaan dan kebutuhan pupuk. Efektivitas distribusi pupuk ditentukan dengan analisis enam tepat distribusi pupuk sedangkan efisiensi diukur dengan menggunakan marjin pemasaran. Hasil penelitian menunjukkan ketersediaan dan kebutuhan pupuk di Kabupaten Bantul bersifat fluktuatif dengan kecenderungan beberapa bulan terjadi kelangkaan stok pupuk. Distribusi pupuk secara keseluruhan cukup efektif dan efisien namun terkadang masih belum tepat jumlah dan tepat harga serta alurnya tidak sesuai ketentuan resmi yang ditetapkan pemerintah. Masalah dalam distribusi pupuk di Bantul antara lain database ketersediaan dan kebutuhan pupuk tidak lengkap, pengecer menjual pupuk kepada selain kelompok tani sedangkan petani membeli tidak melalui kelompok tani, lokasi pengecer terlalu jauh dari lokasi petani, dan harga pupuk di atas Harga Eceran Tertinggi.
\end{abstract}

Kata kunci : Kabupaten Bantul, efektif, efisien, pupuk bersubsidi

\section{ABSTRACT}

The purpose of this study was to know the availability and needs, to evaluate and to formulate the suggestion for fertilizer distribution in Bantul Regency Daerah Istimewa Yogyakarta Province. The study was conducted in May and June 2017. Research respondents were distributors, retailers, farmer groups and farmers. Trend analysis was used to determine the availability and demand of fertilizer. The effectiveness of fertilizer distribution was determined by the six precise of the distribution of fertilizer while efficiency was measured by using marketing margin. The results showed that the availability and the need of fertilizer is fluctuative with the tendency of scarcity in few months. As a whole, the distribution of fertilizer has been quite effective and efficient but sometimes the amount and the price of fertilizer for farmers was not correct and the distribution was not in accordance with the regulation. The problems in the distribution of fertilizer are the incomplete database of the availability and the 
need of fertilizer, the retailers were not selling the fertilizer to the farmer groups while the farmers were not buying from the farmer groups, the location of the retailer is too far from the farmer and the price of fertilizer in over of highest price recommended by the government.

Keywords : Bantul regency, effective, efficient, subsidized fertilizer

\section{PENDAHULUAN}

Peraturan Menteri Perdagangan No.15/ MDAG/PER/4/2013 tentang pengadaan dan penyaluran pupuk bersubsidi untuk sektor pertanian mengatur pendistribusian pupuk bersubsidi kepada petani harus melewati empat lini distribusi. Lini I adalah lokasi gudang pupuk di wilayah pabrik produsen atau di wilayah pelabuhan tujuan untuk pupuk impor. Lini II adalah lokasi gudang produsen di wilayah ibukota provinsi atau Unit Pengantongan Pupuk (UPP) atau di luar wilayah pelabuhan. Lini III adalah lokasi gudang produsen dan atau distributor di wilayah kabupaten atau kota yang ditetapkan produsen. Distributor memiliki kewajiban untuk menjamin kelancaran penyaluran pupuk bersubsidi berdasarkan prinsip 6 (enam) tepat antara lain: tepat jenis, jumlah, harga, tempat, waktu, dan mutu. Sedangkan lini IV adalah lokasi gudang atau kios pengecer di wilayah kecamatan dan atau desa yang ditetapkan distributor. Pengecer resmi memiliki tanggung jawab atas penyaluran pupuk bersubsidi kepada kelompok tani di wilayah yang telah menjadi tanggung jawabnya.

Kebijakan pupuk bersubsidi terbukti mampu meingkatkan luas areal panen dan produksi padi nasional (Hermawan, 2014; Santoso, 2015). Selain itu, kebijakan subsidi harga pupuk menyebabkan seluruh sektor perekonomian dapat menambah outputnya serta meningkatkan pendapatan rumah tangga (Kasiyati, 2010). Namun program pupuk bersubsidi belum efektif mengingat masih banyak persoalan, diantaranya maraknya ekspor pupuk ilegal, pasar pupuk domestik tanpa diikuti pengawasan dan penerapan sanksi secara ketat sehingga distribusi pupuk bersubsidi belum tepat sasaran, distribusi belum efektif dan efisien, ketersediaan pupuk di petani masih langka karena perencanaan yang kurang akurat, pelaku pasar berspekulasi dengan menimbun pupuk bersubsidi, adanya fanatisme petani terhadap merk pupuk tertentu, harga pupuk di atas harga eceran tertinggi (HET) dan banyak distributor pupuk tidak memiliki armada dan gudang penyimpanan sehingga biaya yang dikeluarkan sangat mahal (Nuraini, 2007; Fitriana, 2008; Syafaat, et al dalam Hendrawan, dkk, 2011; Rachman, 2012; Safitri, dkk, 2013; Pramita, dkk, 2016). Walaupun distribusi pupuk bersubsidi mengalami berbagai masalah, petani masih tetap memiliki motivasi tinggi untuk menggunakan pupuk bersubsidi (Kuadarati dan Kusmiati, 2010).

Fakta yang terjadi di daerah lain mengharuskan Pemerintah Kabupaten Bantul berkewajiban memastikan pupuk bersubsidi yang sampai ke tangan petani sesuai dengan asas enam tepat sehingga tujuan program subsidi pupuk dapat tercapai. Distribusi pupuk di Kabupaten Bantul terindikasi masih ada kecurangan. Oknum tertentu membeli pupuk bersubsidi kemudian membuatnya menjadi pupuk tablet dan menjual dengan harga non subsidi serta menyebabkan kelangkaan pupuk bersubsidi (Ariyanti, 2015). Untuk itu, dilaksanakan penelitian ini karena terdapat permasalahan distribusi pupuk di Kabupaten Bantul yang belum terselesaikan serta belum ada kajian mengenai distribusi pupuk di Kabupaten Bantul. Tujuan kajian ini untuk mengetahui ketersediaan dan kebutuhan pupuk bersubsidi, mengevaluasi pelaksanaan distribusi pupuk dan merumuskan saran kebijakan dalam rangka pengembangan distribusi pupuk yang efektif dan efisien di Kabupaten Bantul.

\section{METODE PENELITIAN}

Kajian ini dilaksanakan pada Mei dan Juni 2017 di Kabupaten Bantul. Jenis data 
yang digunakan dalam kajian ini adalah data primer dan data sekunder. Data primer diperoleh melalui wawancara langsung dengan responden maupun dari informan yang relevan. Data sekunder didapat dari Dinas Pertanian, Pangan, Kelautan, dan Perikanan Kabupaten Bantul; Dinas Perdagangan Kabupaten Bantul serta data dari Badan Pusat Statistik (BPS).

Responden dalam penelitian ini antara lain distributor, pengecer, kelompok tani dan petani yang terkait distribusi pupuk di Kabupaten Bantul. Distributor dan pengecer dipilih dengan metode sensus. Jumlah distributor pupuk di Kabupaten Bantul ada 7 unit sedangkan jumlah pengecer ada 48 unit. Untuk kelompok tani dipilih secara purposive sampling yakni kelompok tani mewakili Kabupaten Bantul berdasarkan zonasi wilayah yakni kelompok tani di wilayah Kecamatan Dlingo (Bantul sebelah timur dan berbatasan langsung dengan Kabupaten Gunungkidul) ada 7 kelompok tani (Ngudi Lestari, Ngudi Laras, Amrih Lestari, Amrih Makmur, Amrih Maju, Ngudi Widodo dan Sidodadi), Kecamatan Srandakan (Bantul sebelah barat dan berbatasan langsung dengan Kabupaten Srandakan) ada 6 kelompok tani (Lembah Subur, Ngudi Raharjo, Ngudi Mulyo, Sido Makmur, Candi Lestari dan Subur) serta Kecamatan Bambanglipuro (Bantul bagian tengah) ada 8 kelompok tani (Sido Rukun, Sido Makmur 1, Sido Makmur 2, Sido Makmur 3, Roso Manunggal, Kismo Rumekso, Eko Karyo dan Sumber Makmur). Dari kelompok tani tersebut, kemudian diambil sampel responden yang terdiri dari 21 orang pengurus kelompok dan 27 anggota kelompok tani yang dipilih secara acak (simple random sampling).

Pada kajian ini, untuk mengetahui ketersediaan dan kebutuhan pupuk bersubsidi di Kabupaten Bantul dilakukan dengan membandingkan informasi atau data di antara berbagai stakeholder, teknik ini biasa disebut sebagai triangulasi.

Efektivitas distribusi pupuk bersubsidi oleh pemerintah dianalisis melalui indikator enam tepat, yaitu tepat jenis (kesesuaian jenis pupuk yang digunakan petani dengan rekomendasi), tepat harga (harga yang diterima petani saat melakukan pembelian pupuk bersubsidi sesuai dengan Harga Eceran Tertinggi), tepat mutu (petani selalu mendapatkan pupuk bersubsidi sesuai dengan mutu yang ditetapkan oleh produsen pupuk), tepat waktu (ada atau tidaknya pupuk bersubsidi di pasaran ketika tiba waktu untuk menggunakan pupuk tersebut), tepat tempat (jarak petani membeli pupuk bersubsidi dengan lahan usahataninya) dan tepat jumlah (dosis yang digunakan petani sesuai anjuran yang pemerintah untuk melakukan pemupukan berimbang).

Persentase petani yang menggunakan pupuk bersubsidi sesuai prinsip tepat jenis / jumlah / harga / tempat / waktu / mutu dihitung menggunakan rumus (Arisandi dkk, 2016) :

$$
K x=\frac{N j}{N} \times 100 \%
$$

\section{Keterangan :}

$\mathrm{Kx}=$ Ketepatan tepat jenis / jumlah / harga / tempat / waktu / mutu (\%)

$\mathrm{Nj}=$ Jumlah responden yang menggunakan pupuk bersubsidi tepat jenis / jumlah / harga / tempat / waktu / mutu (Orang)

$\mathrm{N}=$ Jumlah responden total (Orang)

Kriteria penilaian efektivitas pupuk bersubsidi di Kabupaten Bantul, Daerah Istimewa Yogyakarta berdasarkan indikator enam tepat adalah sebagai berikut (Arisandi dkk, 2016) :

$\mathrm{k} \leq 40 \%$, berarti sangat tidak efektif

$40 \% \leq \mathrm{k} \leq 60 \%$, berarti tidak efektif

$60 \% \leq \mathrm{k} \leq 80 \%$, berarti cukup efektif

$80 \% \leq \mathrm{k} \leq 90 \%$, berarti efektif

$90 \% \leq \mathrm{k} \leq 100 \%$, berarti sangat efektif

Untuk mengukur efisiensi distribusi dapat diuji menggunakan nilai marjin yang diketahui dengan menggunakan perhitungan rumus sebagai berikut (Jumiati, dkk, 2013): 
Keterangan :

$$
\mathrm{M}=\mathrm{Pk}-\mathrm{Pp}
$$

$$
\begin{aligned}
& \mathrm{M}=\text { Marjin distribusi } \\
& \mathrm{Pk}=\text { Harga di kelompok tani }(\mathrm{Rp}) \\
& \mathrm{Pp}=\text { Harga di distributor }(\mathrm{Rp})
\end{aligned}
$$

\section{HASIL DAN PEMBAHASAN}

\section{Ketersediaan dan Kebutuhan Pupuk Bersubsidi di Kabupaten Bantul}

Ketersediaan dan kebutuhan merupakan salah 1 masalah penting dalam distribusi pupuk bersubsidi di tingkat petani. Petani sering menghadapi kondisi kelangkaan pupuk bersubsidi pada awal musim tanam padi. Ketersediaan dan kebutuhan pupuk bersubsidi di Kabupaten Bantul tersaji pada Gambar 1.

Berdasarkan wawancara dengan pelaku distribusi pupuk di Kabupaten Bantul diketahui bahwa terdapat kecenderungan dimana pada awal tahun 2017 (Januari-Maret) jumlah ketersediaan pupuk bersubsidi (Urea, SP36, ZA dan Phonska) mampu memenuhi kebutuhan pupuk. Analisis bulan selanjutnya tidak dapat dilakukan karena penelitian ini dilaksanakan pada awal Mei sehingga data ketersediaan dan kebutuhan pupuk bersubsidi yang ada hanya antara bulan Januari - Maret 2017. Namun berdasarkan pengalaman tahun sebelumnya, pada bulan April dan Mei terjadi peningkatan kebutuhan pupuk karena sudah dimulainya kegiatan tanam sehingga terjadi kekurangan pupuk di Kabupaten Bantul. Pada bulan Juni dan Juli kebutuhan pupuk petani mulai berkurang sehingga terjadi surplus ketersediaan pupuk bersubsidi di Kabupaten Bantul. Hal ini menunjukkan terjadi fluktuasi kebutuhan dan ketersediaan pupuk di Kabupaten Bantul sehingga dibutuhkan langkah manajemen pengelolaan dan penyimpanan pupuk berbasis bulan. Langkah ini untuk menjamin ketersediaan pupuk di tingkat petani sepanjang tahun.

\section{Evaluasi Distribusi Pupuk Bersubsidi di Kabupaten Bantul}

Distributor memperoleh pupuk langsung dari produsen yaitu PT. Pupuk Sriwidjaja dan PT. Pupuk Petrokimia Gresik kemudian disalurkan ke pengecer sesuai dengan peraturan dari Pemerintah. Kabupaten Bantul pada tahun 2017 memiliki 7 distributor untuk menyalurkan pupuk subsidi. Dari seluruh distributor di Kabupaten Bantul, terdapat 4 distributor pupuk subsidi yang menyalurkan pupuk urea dari PT. Pupuk Sriwidjaja dan 3 distributor yang menyalurkan pupuk non urea dari PT. Pupuk Petrokimia Gresik (Tabel 1). Setiap distibutor menyalurkan pupuk dari 1 produsen, kecuali PT. Alam Raya yang sudah menyalurkan semua jenis pupuk bersubsidi dari 2 produsen.
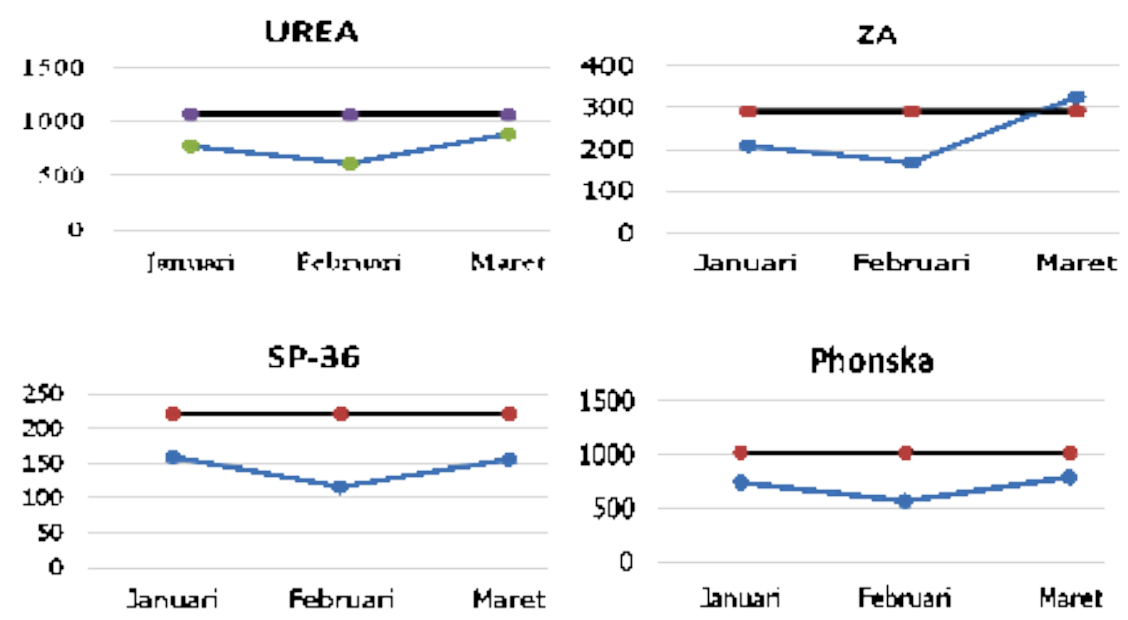

Gambar 1 Kebutuhan dan Ketersediaan Pupuk Bersubsidi di Kabupaten Bantul Tahun 2017 Sumber : Analisis data primer (2017) 
Permasalahan paling dominan dihadapi oleh distributor adalah keterlambatan pengecer dalam menebus pupuk bersubsidi (Tabel 2). Hal ini dapat mengganggu cash flow distributor sehingga selanjutnya distributor kesulitan dalam melakukan penebusan pupuk kepada produsen. Masalah selanjutnya distributor merasa pengecer kurang memahami penyusunan laporan administratif sehingga menyebabkan keterlambatan distributor dalam penyusunan laporan pertanggungjawaban penyaluran pupuk bersubsidi. Permasalahan lain adanya mutu pupuk bersubsidi yang kurang baik sehingga distributor harus melakukan penukaran pupuk kembali. Mutu yang kurang baik ini disebabkan beberapa hal yakni faktor pengiriman pupuk dari produsen sampai dengan gudang di tiap daerah serta faktor penyimpanan yang cukup lama dalam

Tabel 1. Profil Distributor Pupuk Subsidi Wilayah Kerja Kabupaten Bantul Tahun 2017

\begin{tabular}{|c|c|c|c|}
\hline No & Nama & Wilayah Kerja & Pengecer \\
\hline \multirow{5}{*}{1} & \multirow{5}{*}{ CV. Sekar Tani } & Kec. Bantul & 4 \\
\hline & & Kec. Kretek & 5 \\
\hline & & Kec. Bambanglipuro & 2 \\
\hline & & Kec. Sanden & 3 \\
\hline & & Kec. Imogiri & 3 \\
\hline \multirow[t]{4}{*}{2} & \multirow{4}{*}{ CV. Barata Agro } & Kec. Jetis & 4 \\
\hline & & Kec. Kretek & 5 \\
\hline & & Kec. Pundong & 3 \\
\hline & & Kec. Srandakan & 2 \\
\hline \multirow[t]{5}{*}{3} & \multirow{3}{*}{ PT. Alam Raya } & Kec. Pandak & 3 \\
\hline & & Kec. Pajangan & 2 \\
\hline & & Kec. Sedayu & 2 \\
\hline & \multirow{6}{*}{ PT. Alam Raya } & Kec. Bambanglipuro & 2 \\
\hline & & Kec. Sanden & 3 \\
\hline \multirow[t]{5}{*}{4} & & Kec. Bantul & 4 \\
\hline & & Kec. Banguntapan & 2 \\
\hline & & Kec. Sewon & 4 \\
\hline & & Kec. Pleret & 2 \\
\hline & \multirow{4}{*}{ PT Pertani Persero Cab. DIY } & Kec. Piyungan & 4 \\
\hline \multirow[t]{4}{*}{5} & & Kecamatan Dlingo & 2 \\
\hline & & Kec. Imogiri & 3 \\
\hline & & Kec. Sewon & 4 \\
\hline & & Kec. Banguntapan & 2 \\
\hline \multirow{6}{*}{6} & & Kec. Jetis & 4 \\
\hline & PUSKUD METARAM DIY & Kec. Kasihan & 1 \\
\hline & & Kec. Pleret & 2 \\
\hline & & Kec. Pundong & 3 \\
\hline & \multirow{7}{*}{ K3PG } & Kec. Srandakan & 2 \\
\hline & & Kec. Pandak & 3 \\
\hline \multirow{5}{*}{7} & & Kec. Pajangan & 2 \\
\hline & & Kec. Sedayu & 2 \\
\hline & & Kec. Kasihan & 1 \\
\hline & & Kec. Dlingo & 2 \\
\hline & & Kec. Piyungan & 4 \\
\hline
\end{tabular}

Sumber : Analisis Data Sekunder, 2017 
Tabel 2. Permasalahan di Tingkat Distributor

\begin{tabular}{llcr}
\hline No & \multicolumn{1}{c}{ Hambatan } & Jumlah & \% \\
\hline 1 & Keterlambatan pengecer menebus pupuk & 4 & 36,36 \\
2 & Manajemen pengecer dalam hal administrasi & 3 & 27,27 \\
3 & Mutu pupuk & 2 & 18,18 \\
4 & Keterbatasan transportasi & 1 & 9,09 \\
5 & Kesalahan laporan hasil verifikasi dan validasi & 1 & 9,09 \\
\hline \multicolumn{2}{l}{ Jumlah } & 11 & 100,00 \\
\hline
\end{tabular}

Sumber: Analisis Data Primer, 2017

gudang. Penukaran ini dapat merugikan distributor karena harus mengeluarkan lebih banyak biaya tambahan menukarkan pupuk di gudang pengambilan. Permasalahan keempat adalah mengenai keterbatasan transportasi pada saat akhir tahun dimana permintaan pengiriman pupuk bersubsidi meningkat serta terjadi kepadatan lalu lintas, sedangkan armada pengangkutan yang tersedia terbatas. Permasalahan terakhir yang ditemukan di tingkat distributor yakni mengenai terjadinya kesalahan laporan hasil verifikasi dan validasi.

Pengecer merupakan pihak yang menyalurkan pupuk bersubsidi dari distributor ke kelompok tani. Pengecer dapat berupa kios maupun KUD dengan satu penanggung jawab. Wilayah kerja pengecer diatur oleh pemerintah sehingga tidak diperbolehkan menjual pupuk subsidi di luar ketentuan. Pengecer dapat membawahi beberapa kelompok tani di satu desa atau pengecer memiliki jangkauan penyaluran dalam desa.

Permasalahan paling dominan ditemukan pada pengecer adalah kualitas pupuk kurang baik yang disebabkan penyimpanan dalam gudang yang cukup lama (Tabel 4). Keterlambatan pengecer dalam menebus stok pupuk kepada distributor menyebabkan stok menumpuk dalam gudang distributor, sehingga pupuk yang sudah lama berada dalam gudang akan mengalami penurunan kualitas. Permasalahan kedua yakni permasalahan administrasi. Banyaknya administrasi penebusan, penyaluran hingga laporan pertanggungjawaban yang harus dibuat oleh pengecer dirasa memberatkan. Permasalahan ketiga yakni mengenai berat pupuk subsidi yang tidak sesuai standar. Hal ini salah satunya diakibatkan penyimpanan pupuk dalam gudang yang terlalu lama. Faktor penyimpanan juga mempengaruhi kemasan karung pupuk yang menjadi mudah

Tabel 3. Jangkauan Wilayah Penyaluran Pupuk Bersubdi dari Pengecer

\begin{tabular}{lccc}
\hline No & Jangkauan Penyaluran & Jumlah (kios) & $\%$ \\
\hline 1 & Dalam Desa & 15 & 31,25 \\
2 & Antar Desa & 33 & 68,75 \\
\hline & Jumlah & 48 & 100,00 \\
\hline
\end{tabular}

Sumber: Analisis Data Primer, 2017

lebih dari satu desa namun tidak akan keluar dari satu kecamatan. Tabel 3 menjelaskan sebanyak 68,75\% pengecer di Kabupaten Bantul memiliki jangkauan penyaluran antar desa. Hal ini berarti satu pengecer membawahi beberapa kelompok tani yang berada di desa berbeda namun masih dalam satu kecamatan. Sisanya sebesar 31,25\% rusak. Kerusakan kemasan karung ini dirasakan oleh sekitar $6,25 \%$ pengecer.

Pelaku distribusi pupuk selanjutnya adalah kelompok tani. Tugas kelompok tani dalam distribusi pupuk subsidi yaitu membeli pupuk dari pengecer kemudian menjual ke petani sesuai dengan kebutuhan pupuk pada Rencana Definitif Kebutuhan Kelompok 
Tabel 4. Permasalahan di Tingkat Pengecer Pupuk Bersubsidi

\begin{tabular}{llcr}
\hline No & Permasalahan & Jumlah & $\%$ \\
\hline 1 & Kualitas pupuk kurang baik & 16 & 33,33 \\
2 & Administrasi & 12 & 25 \\
3 & Berat pupuk kurang sesuai & 6 & 12,5 \\
4 & Keterlambatan penyaluran & 6 & 12,5 \\
5 & Pengemasan karung & 3 & 6,25 \\
6 & Lainnya & 5 & 10,42 \\
\hline & Jumlah & 48 & 100,00 \\
\hline
\end{tabular}

Sumber: Analisis Data Primer, 2017

(RDKK). Kelompok tani juga mendata luas lahan setiap anggota untuk disusun sebagai dasar RDKK. Petani yang tidak ada di RDKK tidak dapat membeli pupuk bersubsidi. Kelompok tani juga harus membeli pupuk bersubsidi sesuai dengan pengecer yang sudah ditunjuk dan ditetapkan oleh pemerintah.

Permasalahan paling dominan kelompok tani adalah penyusunan RDKK (Tabel 5). Fakta di lapangan menunjukkan tidak adanya pembaharuan RDKK sehingga menimbulkan beberapa permasalahan. Salah satu permasalahan yakni ketidaktepatan luas lahan dengan kebutuhan pupuk petani sehingga implementasi di lapangan banyak petani yang masih merasa kekurangan pupuk ataupun ada di wilayah lain yang merasa pupuk melimpah ketersediannya. Tidak adanya pembaharuan RDKK disebabkan kurangnya pemahaman ketua kelompok tani dalam mekanisme penyusunan RDKK serta kurangnya peran aktif anggota kelompok.

Permasalahan kedua adalah mengenai ketersedian stok pupuk di pengecer. Kurang tersedianya stok pada pengecer saat pupuk dibutuhkan oleh petani disebabkan keterbatasan modal yang dimiliki pengecer. Ketidaktersediaan stok pada pengecer yang ditunjuk, menyebabkan petani harus mengundur jadwal pemupukan atau memaksa petani membeli pupuk pada kios lain. Permasalahan selanjutnya adalah sistem pembayaran tunda bayar. Sistem pembayaran seperti ini dirasa banyak merugikan kelompok tani karena anggota yang membayar pelunasan penebusan pupuk tidak tepat waktu sehingga menyebabkan kas kelompok tani habis dan tidak dapat menebus pupuk ke pengecer pada masa tanam berikutnya.

Ukuran efektivitas dan efisiensi sistem distribusi pupuk diukur dari adanya kesesuaian antara alokasi dan realisasi dan sesuai dengan 6 prinsip tepat. Adapun temuan di lapangan antara lain (Tabel 6) :

\section{Tepat Jenis}

Terdapat 5 jenis pupuk yang disubsidi oleh pemerintah yaitu NPK, SP-36, Urea, ZA, dan Petroganik. Jenis pupuk bersubsidi yang

Tabel 5. Permasalahan di Tingkat Kelompok Tani

\begin{tabular}{llcr}
\hline No & \multicolumn{1}{c}{ Permasalahan } & Jumlah \\
\hline 1 & Penyusunan RDKK & 8 & 38,10 \\
2 & Ketersediaan stok pupuk pengecer & 3 & 14,29 \\
$\quad$ Sistem pembayaran anggota kelompok kepada & 3 & 14,29 \\
3 & kelompok tani & 2 & 9,52 \\
4 & Keterlambatan pengiriman pupuk oleh pengecer & 2 & 9,52 \\
5 & Perbedaan waktu pemupukan & 3 & 14,29 \\
6 Lainnya & 48 & 100,00 \\
\hline & Jumlah &
\end{tabular}

Sumber: Analisis Data Primer, 2017 
Tabel 6. Persentase Ketepatan Jenis Pupuk Bersubsidi yang Diterima Petani di Kabupaten Bantul Tahun 2017

\begin{tabular}{cccc}
\hline \multirow{2}{*}{ Macam Ketepatan } & \multicolumn{3}{c}{ Keefektifan (\%) } \\
\cline { 2 - 4 } & Efektif & Cukup Efektif & Tidak Efektif \\
\hline Jenis & 90.48 & 9.52 & 0.00 \\
Waktu & 66.67 & 33.33 & 0.00 \\
Tempat & 61.90 & 38.10 & 0.00 \\
Jumlah & 28.57 & 47.62 & 23.81 \\
Harga & 52.38 & 0.00 & 47.62 \\
Mutu & 71.43 & 14.29 & 14.29 \\
Jumlah & 61,90 & 23,81 & 14,29 \\
\hline
\end{tabular}

Sumber: Analisis Data Primer, 2017

digunakan petani mayoritas telah tergolong efektif dengan persentase sebesar 90,48\%. Sedangkan 9,52\% lainnya tergolong cukup efektif. Hal ini dikarenakan kelima jenis pupuk subsidi dirasa telah mampu memenuhi kebutuhan petani dalam mencukupi unsur hara yang dibutuhkan tanaman.

\section{Tepat Waktu}

Asas tepat waktu adalah waktu seharusnya petani mendapatkan jatah pupuk bersubsidi ketika petani membutuhkan. Sebesar $66,67 \%$ responden menyatakan tergolong efektif yang berarti pupuk bersubsidi tersedia ketika dibutuhkan oleh petani. Namun masih terdapat petani yang menganggap ketersediaan pupuk bersubsidi terkadang tidak selalu tersedia ketika dibutuhkan (33,33\%). Walaupun persentasenya lebih kecil daripada petani yang menganggap distribusi telah efektif, namun keadaan ini juga perlu menjadi perhatian pemerintah. Beberapa faktor yang menyebabkan gangguan dalam ketersediaan pupuk bersubsidi yaitu penyaluran pupuk bersubsidi yang harus mengantri karena tingginya tingkat permintaan pupuk saat musim tanam dan/atau kelompok tani terlambat menebus pupuk di pengecer resmi sehingga petani sebagai anggota tidak memperoleh pupuk bersubsidi sesuai dengan RDKK yang diajukan.

\section{Tepat Tempat}

Pengertian tepat tempat adalah suatu kondisi dimana petani membeli pupuk bersubsidi di lini IV atau kelompok tani sesuai ketentuan. Berdasarkan wawancara, persentase efektif untuk kategori tepat tempat hanya sebesar $61,90 \%$ karena masih terdapat petani yang membeli pupuk bersubsidi tidak pada pengecer resmi yang telah ditentukan. Hal tersebut disebabkan beberapa faktor antara lain jaraknya yang jauh, terlambatnya ketersediaan pupuk bersubsidi di pengecer resmi, kurangnya jatah pupuk urea bersubsidi di pengecer resmi/kelompok tani.

\section{Tepat Jumlah}

Pengertian tepat jumlah adalah jumlah pemupukan yang dilakukan sesuai dengan dosis atau jumlah berdasarkan analisa status hara tanah dan kebutuhan tanaman yang direkomendasi oleh pemerintah. Pemberian jumlah pupuk yang tepat akan membuat pertumbuhan periodik tanaman secara optimal yang dapat dilihat dari tinggi tanaman, diameter batang, jumlah daun dan jumlah cabang (Suyantohadi, dkk 2009).

Berdasarkan wawancara, dapat diketahui bahwa hanya sebesar $28,57 \%$ yang tergolong efektif. Sisanya sebesar $47,62 \%$ dan $23,81 \%$ masing-masing tergolong cukup efektif dan tidak efektif. Hal ini berarti masih terdapat petani yang belum menggunakan rekomendasi aplikasi pupuk bersubsidi dengan baik sehingga jumlah yang dialokasikan pada RDKK kurang efektif. Beberapa faktor yang menyebabkan ketidakefektifan tersebut karena alokasi pupuk yang diperoleh petani hanya untuk komoditas pangan dan palawija. Sedangkan 
beberapa komoditas yang dibudidayakan petani, seperti semangka dan melon, tidak memperoleh pupuk bersubsidi. Dengan begitu, petani kemudian menggunakan alokasi pupuk yang seharusnya untuk komoditas pangan dan palawija kemudian digunakan untuk tanaman lain sehingga penggunaan pupuk untuk tanaman pangan dan palawija cenderung kurang.

Pola seperti ini sebenarnya dapat menyebabkan kelangkaan pupuk di Kabupaten Bantul. Hal ini didukung oleh Darwis dan Saptana (2010) dalam penelitiannya bahwa meskipun kebijakan pupuk sudah banyak dilaksanakan terutama dalam aspek pengadaan, penyaluran, dan pengaturan harga, tetapi kelangkaan pupuk masih sering terjadi yang salah satunya penyebabnya yaitu pemakaian pupuk di tingkat petani yang melebihi dosis anjuran.

\section{Tepat Harga}

Berdasarkan wawancara dengan petani, terdapat $47,62 \%$ petani yang membeli pupuk bersubsidi tidak pada HET yang telah ditentukan. HET pupuk bersubsidi untuk kelima jenis pupuk yang berlaku saat ini yaitu $\mathrm{Rp} 1.800 / \mathrm{kg}$ untuk jenis pupuk Urea, Rp $2.000 / \mathrm{kg}$ untuk jenis pupuk SP-36, Rp 1.400/ $\mathrm{kg}$ untuk jenis pupuk ZA, Rp 2.300/kg untuk jenis pupuk Phonska, dan Rp 500/kg untuk jenis pupuk Petroganik. Persentase keefektifan atau ketepatan harga yang diterima petani sebesar 52,38\%, sedangkan sisanya tergolong tidak efektif atau tidak tepat harga. Pada kenyataannya petani yang membeli pupuk bersubsidi melalui kelompok tani memperoleh harga di atas HET. Hal ini dikarenakan kelompok tani menginginkan keuntungan untuk kas maupun membiayai distribusi pupuk. Walaupun begitu, biasanya perbedaan harga tersebut telah didiskusikan terlebih dahulu saat pertemuan rutin kelompok tani.

Rendahnya efektivitas harga ini sesuai dengan penelitian Mustafa, dkk (2016) yakni biaya angkut yang dilakukan belum efisien dimana PT. Pupuk Sriwijaya perlu meninjau kembali lokasi distribusi dan jumlah alokasi yang telah ditetapkan dengan sistem penyaluran yang dapat menghemat biaya angkut pupuk urea bersubsidi ke kecamatankecamatan di Kabupaten Aceh Besar. Gambaran ini sesuai dengan di Kabupaten Bantul dimana lokasi pengecer yang terkadang jauh dari petani sehingga meningkatkan harga jual pupuk.

\section{Tepat Mutu}

Azas tepat mutu merujuk pada keaslian pupuk bersubsidi yang memiliki standarisasi kualitas pupuk. Selain itu, beberapa jenis pupuk bersubsidi terkadang memiliki kualitas yang kurang baik saat didistribusikan, sehingga petani merasa terganggu dengan kualitas pupuk bersubsidi yang diterima. Besaran ketidakefektifan mutu pupuk bersubsidi di Kabupaten Bantul yaitu masingmasing sebesar 14,29\% untuk kategori cukup efektif dan tidak efektif sedangkan persentase efektif sebesar $71,43 \%$. Temuan ini juga dapat menggambarkan tingkat pengetahuan petani mengenai baik atau buruknya kualitas pupuk bersubsidi yang diterima dengan cara membandingkan kondisi fisik pada tiap pupuk bersubsidi.

Berdasarkan hasil identifikasi saluran pemasaran pupuk bersubsidi di Kabupaten Bantul terbentuk empat jenis saluran pemasaran sebagai berikut :

1. Produsen $\rightarrow$ Distributor $\rightarrow$ Pengecer $\rightarrow$ Petani (Anggota Kelompok Tani)

2. Produsen $\rightarrow$ Distributor $\rightarrow$ Pengecer $\rightarrow$ Kelompok Tani $\rightarrow$ Petani (Anggota Kelompok Tani)

3. Produsen $\rightarrow$ Distributor $\rightarrow$ Pengecer $\rightarrow$ Warung $\rightarrow$ Petani (Anggota Kelompok Tani)

4. Produsen $\rightarrow$ Distributor $\rightarrow$ Pengecer $\rightarrow$ Warung $\rightarrow$ Petani (Anggota Kelompok Tani) $\rightarrow$ Masyarakat (Petani Non Anggota Kelompok Tani).

Menurut peraturan yang telah disebutkan dalam Peraturan Menteri Perdagangan Republik Indonesia No. 15/M-Dag/Per/4/2013 bahwa pengecer resmi 
selaku lini IV harus menyalurkan pupuk bersubsidi kepada kelompok tani sesuai dengan HET. Apabila mengacu pada peraturan tersebut seharusnya saluran II menjadi saluran yang paling dominan pada distribusi pupuk bersubsidi di Kabupaten Bantul. Akan tetapi, fakta di lapangan memperlihatkan bahwa sebagian besar distribusi pupuk bersubsidi di Kabupaten Bantul menggunakan pola saluran I dibandingkan saluran II. Fenomena ini dikarenakan beberapa alasan, antara lain dekatnya jarak antara kios pengecer resmi dengan rumah petani atau lahan sawah petani, keputusan kelompok tani untuk memperbolehkan anggota membeli langsung ke pengecer resmi, tidak tersedianya pupuk bersubsidi di kios pengecer resmi dan waktu pemupukan petani yang tidak serempak sehingga kebutuhan anggota kelompok tani tidak bersamaan.

Pada saluran II, kelompok tani mengambil fee sebagai kas kelompok sehingga harga pupuk subsidi lebih mahal daripada saluran pertama. Kelompok tani biasanya menebus pupuk terlebih dahulu untuk kepentingan anggota dan sewajarnya apabila kelompok tersebut kemudian mengambil fee untuk meningkatkan kemampuan finansial kelompok.

Pada saluran III dan saluran IV dimana terdapat warung (kios tidak resmi) yang

Tabel 7. Rerata Marjin Pemasaran Pupuk Urea Bersubsidi pada Setiap Lembaga Distribusi di Kabupaten Bantul Tahun 2017

\begin{tabular}{|c|c|c|c|c|}
\hline \multirow{2}{*}{ Lembaga Distribusi } & \multicolumn{4}{|c|}{ Saluran Distribusi (Rp/Kg) } \\
\hline & I & II & III & IV \\
\hline \multicolumn{5}{|l|}{ Distributor } \\
\hline Harga Tebus & $1.637,27$ & $1.637,27$ & $1.637,27$ & $1.637,27$ \\
\hline Harga Jual & $1.731,82$ & $1.731,82$ & $1.731,82$ & $1.731,82$ \\
\hline Marjin Distributor & 94,55 & 94,55 & 94,55 & 94,55 \\
\hline \multicolumn{5}{|l|}{ Pengecer Resmi } \\
\hline Harga Tebus & $1.731,82$ & $1.731,82$ & $1.731,82$ & $1.731,82$ \\
\hline Harga Jual & $1.900,00$ & $1.800,00$ & $1.800,00$ & $1.800,00$ \\
\hline Marjin Pengecer Resmi & 168,18 & 68,18 & 68,18 & 68,18 \\
\hline \multicolumn{5}{|l|}{ Warung } \\
\hline Harga Tebus & - & - & $1.800,00$ & $1.800,00$ \\
\hline Harga Jual & - & - & $2.000,00$ & $2.000,00$ \\
\hline Marjin Warung & & & 200,00 & 200,00 \\
\hline \multicolumn{5}{|l|}{ Kelompok Tani } \\
\hline Harga Tebus & - & $1.800,00$ & - & - \\
\hline Harga Jual & - & $2.000,00$ & - & - \\
\hline Marjin Kelompok Tani & & 200,00 & & \\
\hline \multicolumn{5}{|l|}{ Petani } \\
\hline Harga Tebus & $1.900,00$ & $2.000,00$ & $2.000,00$ & $2.000,00$ \\
\hline Harga Jual & - & - & - & $2.500,00$ \\
\hline Marjin Petani & & & & 500,00 \\
\hline \multicolumn{5}{|l|}{$\begin{array}{lll}\text { Petani } & \text { Non } & \text { Anggota }\end{array}$} \\
\hline Kelompok Tani & & & & \\
\hline Harga Tebus & - & - & - & $2.500,00$ \\
\hline Total Marjin & 262,37 & 362,73 & 362,73 & 862,73 \\
\hline
\end{tabular}

Sumber: Analisis Data Primer 2017 
mendistribusikan pupuk bersubsidi kepada petani. Hal ini dikarenakan lokasi warung (kios tidak resmi) yang lebih dekat dengan rumah atau lahan petani sehingga petani merasa tercukupi dengan membeli kebutuhan pupuk bersubsidi di warung tersebut. Pada saluran IV, masyarakat atau petani non anggota kelompok tani dapat membeli pupuk bersubsidi melalui petani dan hal ini tidak sesuai dengan ketentuan distribusi pupuk sehingga perlu ada tindakan hukum dari Pemerintah Kabupaten Bantul. Hasil ini juga sesuai penelitian Safitri, dkk (2013) mengenai distribusi pupuk subsidi kepada petani tebu di Kabupaten Malang dimana pengawasan penyaluran pupuk subsidi masih terbilang kurang karena ada pengecer yang menyediakan pupuk untuk wilayah yang bukan tanggung jawabnya serta belum ada sanksi yang nyata yang dilakukan oleh tim pengawas untuk mengatasi hal ini.

Analisis marjin pemasaran merupakan salah satu alat analisis untuk melihat tingkat efisiensi distribusi pupuk bersubsidi. Berdasarkan hasil analisis dapat diketahui bahwa distributor membeli pupuk urea bersubsidi dari produsen sebesar Rp 1.637,27/ $\mathrm{kg}$ yang selanjutnya disebut sebagai harga tebus di tingkat distributor (Tabel 7). Harga jual di tingkat distributor merupakan harga jual distributor kepada pengecer resmi atau harga beli pengecer resmi dari distributor yaitu sebesar Rp 1.731,818/kg. Harga tebus di tingkat distributor dan harga jual di tingkat distributor sudah ditentukan oleh PT. Pusri selaku produsen pupuk urea bersubsidi untuk wilayah Kabupaten Bantul. Oleh sebab itu, harga tebus dan harga jual di tingkat distributor pada saluran I sampai dengan saluran IV terdapat persamaan. Harga tebus pupuk urea bersubsidi di tingkat pengecer resmi sama dengan harga jual di tingkat distributor, sehingga harga tebus pupuk urea bersubsidi oleh pengecer pada saluran I - IV terdapat persamaan. Harga tebus pupuk urea bersubsidi di petani pada saluran I lebih rendah dibandingkan ketiga saluran lainnya. Perbedaan harga pupuk urea bersubsidi yang diterima petani terjadi karena petani langsung membeli dari pengecer resmi atau tidak melewati kelompok tani sebagaimana mestinya. Saluran II, III, dan IV melibatkan lebih banyak lembaga distribusi dibandingkan saluran I sehingga harga tebus yang diterima oleh petani lebih tinggi.

Marjin pemasaran saluran I lebih kecil dibandingkan ketiga saluran lainnya karena saluran I memiliki jumlah lembaga distribusi yang lebih sedikit daripada ketiga saluran lain. Fungsi, biaya dan keuntungan pemasaran saluran I lebih kecil dari saluran lain karena pelaku distribusi yang lebih sedikit. Pada saluran II, petani membeli pupuk urea bersubsidi dari kelompok tani dengan keuntungan penjualan pupuk tersebut digunakan untuk kesejahteraan anggota kelompok.

Semakin besar marjin pemasaran maka tingkat efisiensi akan semakin rendah. Hal ini memperlihatkan bahwa saluran IV merupakan saluran dengan efisiensi pemasaran paling rendah karena memiliki marjin pemasaran terbesar, sedangkan saluran I merupakan saluran dengan efisiensi pemasaran paling tinggi. Urutan saluran pemasaran menurut efisiensi pemasaran paling tinggi secara berturut-turut yaitu saluran I, II dan III serta IV.

\section{Rekomendasi Perbaikan Distribusi Pupuk di Kabupaten Bantul}

Berdasarkan masalah yang telah diidentifikasi, maka diperlukan beberapa langkah perbaikan dalam distribusi pupuk di Kabupaten Bantul yakni

\section{1) Perbaikan database ketersediaan dan kebutuhan pupuk (RDKK)}

Data ketersediaan dan kebutuhan pupuk bersubsidi belum diarsipkan dengan baik sedangkan penyusunan RDKK tani tidak sesuai dengan kondisi riil. Untuk itu, diperlukan penyusunan database ketersediaan dan kebutuhan pupuk dengan baik dan terintegrasi yang membantu untuk melakukan kajian lebih lanjut serta mengambil kebijakan dengan tepat.

\section{2) Sosialisasi alur resmi distribusi pupuk bersubsidi bagi pengecer dan petani}


Sosialisasi bagi pengecer dan petani perlu dilakukan karena banyak terjadi penyelewengan distribusi pupuk. Pemerintah Kabupaten Bantul perlu mensosialisasikan aturan distribusi yang tepat kepada pengecer dan petani sehingga alur distribusi sesuai dengan aturan yang ada.

\section{3) Penataan manajemen usaha kelompok tani}

Salah satu penyebab penyimpangan perilaku petani dalam membeli pupuk adalah masih lemahnya peran kelompok tani dalam mengelola distribusi pupuk. Untuk mencapai manajemen kelompok tani yang ideal, maka Pemerintah Kabupaten Bantul perlu terus melakukan penyuluhan dan pendampingan baik dalam manajemen administrasi kelompok maupun manajemen usaha kelompok.

4) Penataan lokasi ataupun skala usaha pengecer agar petani membeli pupuk tepat lokasi

Penataan utama terkait lokasi pelaku distribusi pupuk terutama pengcer dalam rangka meningkatkan kinerja pengecer. Pengaturan lokasi pengecer seharusnya dengan mempertimbangkan jarak tempuh distribusi yang dekat, biaya transportasi, dan panjang saluran dengan penataan ulang lembaga tata niaga distribusi pupuk bersubsidi.

\section{5) Penetapan batas bawah dan atas biaya transportasi distribusi pupuk}

Pengaturan biaya transportasi melalui tarif batas biaya untuk mengakomodir kepentingan masing-masing pemangku kepentingan (distributor, pengecer, kelompok tani). Batas bawah biaya transportasi berfungsi agar pengecer tidak mengalami kerugian sedangkan batas atas biaya transportasi agar petani memperoleh harga pupuk yang layak.

\section{6) Peningkatan peran badan pengawas}

Pemerintah Kabupaten Bantul melalui

Komisi Pengawasan Pupuk dan Pestisida (KP3) perlu untuk mengontrol pelaksanaan distribusi pada masing-masing lembaga distribusi agar penyaluran pupuk bersubsidi dapat efektif dan efisien. Pengawasan secara langsung dan menyeluruh dengan melibatkan seluruh anggota KP3 berdasarkan tugas dan fungsinya masing-masing.

\section{SIMPULAN}

Ketersediaan dan kebutuhan pupuk di Kabupaten Bantul bersifat fluktuatif dengan kecenderungan ada beberapa bulan yang mengalami kelangkaan stok pupuk. Distribusi pupuk di Kabupaten Bantul secara keseluruhan cukup efektif dan efisien namun terkadang masih terjadi belum tepat jumlah dan tepat harga serta alurnya tidak sesuai dengan ketentuan resmi yang ditetapkan pemerintah. Masalah dalam distribusi pupuk di Kabupaten Bantul antara lain database ketersediaan dan kebutuhan pupuk tidak lengkap, pengecer menjual pupuk kepada selain kelompok tani sedangkan petani membeli pupuk tidak melalui kelompok tani, petani keberatan dengan fee kepada kelompok tani sehingga petani membeli pupuk langsung kepada pengecer ataupun membeli pupuk kepada kelompok tani namun di atas Harga Eceran Tertinggi, lokasi pengecer yang terlalu jauh dari lokasi petani, harga pupuk di atas HET karena adanya tambahan biaya transportasi dan masih banyak penyelewengan distribusi pupuk.

\section{UCAPAN TERIMA KASIH}

Ucapan terima kasih tujukan kepada Dinas Perdagangan Kabupaten Bantul yang merupakan pemberi dana penelitian ini.

\section{DAFTAR PUSTAKA}

Ariyanti, S. 2015. Polisi turun tangan atasi kecurangan penjualan pupuk subsidi. http://jogja.tribunnews.com/2015/03/01/p olisi-turun-tangan-atasi-kecuranganpenjualan-pupuk-subsidi.Diakses tanggal 5 Januari 2018.

Arisandi., N. W. W., I. M. Sudarma, dan I. K. Rantau. 2016. Efektivitas distribusi pupuk organik dan dampaknya terhadap pendapatan usahatani padi sawah di 
Subak Sungsang, Desa Tibubiu, Kabupaten Tabanan. E-Jurnal Agribisnis dan Agrowisata 5(1): 1-10.

Darwis V, dan Saptana. 2010. Rekonstruksi kelembagaan dan uji teknologi pemupukan : kebijakan strategis mengatasi kelangkaan pupuk. Analisis Kebijakan Pertanian 8(2): 167-186.

Fitriana, W. 2008. Analisis sistem distribusi pupuk bersubsidi di Sumatera Barat (studi kasus : PT Pupuk Sriwijaya cabang Sumbar). Jurnal Agribisnis Kerakyatan 1(2): 58-65.

Hendrawan, D., D. Arief., S. Bunsor, dan S. Hermanto. 2011. Analisis kebijakan subsidi pupuk : penentuan pola subsidi dan sisten distribusi pupuk di Indonesia. Jurnal Manajemen dan Agribisnis 8(2): 85-96.

Hermawan, I. 2014. Analisis dampak kebijakan subsidi pupuk urea dan tsp terhadap produksi padi dan capaian swasembada pangan di Indonesia. Jurnal Ekonomi \& Kebijakan Publik 5(1): 63 78.

Jumiati, E., D. H Darwanto., S. Hartono, dan Masyhuri. 2013. Analisis saluran pemasaran dan marjin pemasaran kelapa dalam di daerah perbatasan Kalimantan Timur. Jurnal Agrifor 12(1): 1-10.

Kasiyati, S. 2010. Analisis dampak subsidi harga pupuk terhadap output sector produksi dan tingkat pendapatan rumah tangga di Jawa Tengah (pendekatan analisis i-o dan snse Jawa Tengah tahun

2004). Jurnal Organisasi dan Manajemen 6(1): 28-45.

Kuadarati, D. K dan A. Kusmiati. 2010. Faktor-faktor yang berperan dalam kelangkaan pupuk bersubsidi. Journal of Social and Agricultural Economics 4(1): 63-80.

Mustafa, S. I., Amri dan Sulaiman. 2016.
Analisa biaya penyaluran pupuk urea bersubsidi dengan memakai metode stepping stone di Kabupaten Aceh Besar. Jurnal Manajemen 5(1): 68-75.

Nuraini, L. 2007. Instrumen kebijakan pupuk bersubsidi bagi petani Indonesia. Jurnal Ilmu Administrasi dan Kebijakan Publik 4(1): 62-68.

Pramita, K.D., P. Utami dan Dumasari. 2016. Analisis tata niaga pupuk bersubsidi di Kabupaten Purbalingga. Agritech 18(1): 25-29.

Rachman, B. 2012. Tinjauan kritis dan perspektif sistem subsidi pupuk. Jurnal Penelitian dan Pengembangan Pertanian 31(3): 119-127.

Safitri, M. A., S. Bambang dan R. Heru. 2013. Distribusi pupuk subsidi kepada petani tebu dalam perspektif manajemen publik (studi pada koperasi unit desa di Sumberpucung Kabupaten Malang). Jurnal Administrasi Publik (JAP) 1(1): 102-109.

Santoso, A. B. 2015. Pengaruh luas lahan dan pupuk bersubsidi terhadap produksi padi Nasional. Jurnal Ilmu Pertanian Indonesia 20(3): 208-212.

Suyantohadi, A., H. Mochamad, dan H. P. Mauridhi. 2009. Identifikasi pertumbuhan tanaman kedelai dengan pengaruh pemberian komposisi pupuk menggunakan metoda artifiacial neural network. Agritech 29(4): 219-227. 